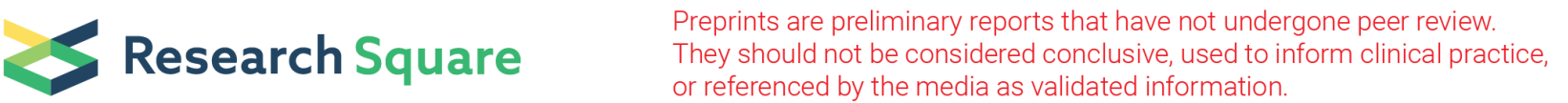 \\ Headache in the emergency department in Chongqing Province, China: A multicentre study
}

\section{Qin Li}

The First Affiliated Hospital of Chongqing Medical University and Chongqing General Hospital, University of Chinese Academy of Sciences

Tao Ye

Chongqing General Hospital, University of Chinese Academy of Sciences

\section{Jingxi Ma}

Chongqing General Hospital, University of Chinese Academy of Sciences

\section{Dongli Yuan}

Chongqing Medical University

\section{Xuemei Peng}

Chongqing General Hospital, University of Chinese Academy of Sciences

\section{Min Cai}

Chongqing General Hospital, University of Chinese Academy of Sciences

\section{Zhengwei Xi}

Fuling Central Hospital

\section{Yujiao Zhang}

The First Affiliated Hospital of Chongqing Medical University

\section{Qinlin Liu}

The First Affiliated Hospital of Chongqing Medical University

\section{Ge Tan ( $\square$ 273346692@qq.com )}

The First Affiliated Hospital of Chongqing Medical University and Chongqing General Hospital, University of Chinese Academy of Sciences https://orcid.org/0000-0002-1530-7377

\section{Research}

Keywords: Headache, Migraine, Emergency department, Primary headache, Secondary headache

Posted Date: November 13th, 2020

DOI: https://doi.org/10.21203/rs.3.rs-106514/v1

License: (ㄷ) (1) This work is licensed under a Creative Commons Attribution 4.0 International License. Read Full License 


\section{Abstract}

Background: To investigate the present situation of emergency headache in many general hospitals in Chongqing Province, China.

Methods: From January 1 to December 31, 2017, we studied patients who complained of headaches as the main symptom in the emergency department of 17 general hospitals in Chongqing Province. Each patient with a headache was interviewed and the medical history was collected by administering a questionnaire. The diagnosis of headache is based on the third edition of the International Classification of Headache Disorders (ICHD-3 beta).

Results: In 2017, 16434 patients complained of headache in 17 general hospitals in Chongqing, accounting for $2.3 \%$ of all emergency patients. Eight thousand one male patients (48.7\%) and 8433 female patients (51.3\%) experienced a headache. The average age was $(41.8 \pm 13.2)$ years, and the course of disease was 3 hours to 15.2 years. Regarding the initial diagnosis, 7299 patients (44.4\%) were diagnosed secondary headache, 5076 (30.9\%) were diagnosed with primary headache and 4059 (24.865\%) could not be diagnosed. The hospitalization rates for these patients were $60.3 \%, 12.2 \%$, and $41.5 \%$, respectively. Migraine is still the most common type of primary headache.

Conclusions: This study shows that the misdiagnosis rate and missed diagnosis rate of patients with an emergency headache are high, and the emergency department still performs overtesting and hospitalizations.

\section{Introduction}

Headaches add to the burden on society and families [1]. Patients with severe headache often visit the emergency department. Acute severe headache often challenges health resources and emergency physicians. Accurate results from epidemiological research are very important for medical and health management departments to formulate relevant prevention and control policies and allocate emergency resources. At the same time, they can guide clinicians to conduct more targeted medical practices in the outpatient department, emergency department and ward.

In the United States, up to 1-4\% of emergency department visits is caused by headache [2, 3]. Recently, a study on selfreported migraine or severe headache in the United States shows that approximately one in six Americans has been affected by headache in the past three months, and one in five women has been affected by headache [4]. Because different countries and hospitals have different diagnostic methods and levels, the results of research differ. In China, emergency physicians treat many patients with acute headache. Currently, research data on emergency headache in China are lacking. This study used the third edition of the International Classification of Headache Disorders (ICHD-3 beta) [5] to study the patients presenting with headache as the main symptom in the emergency department of 17 general hospitals in Chongqing Province in 2017.

\section{Data And Methods}

\section{General information}

The continuous group method was used in the present study. Data were collected from patients with headache as the main symptom at the emergency department of 17 general hospitals in Chongqing from January 1 to December 31, 2017. The age, gender, previous medical history, headache duration, auxiliary examination and treatment of the patients were recorded.

\section{Methods}

Patients were first treated and registered in the emergency department. They were initially identified by emergency physicians. Headache was the main symptom of each patient. Then, the neurologist will perform a consultation, inquire about the detailed medical history, perform a standardized physical examination, determine the relevant examinations required for diagnosis, and determine a preliminary diagnosis and treatment. Some patients may be hospitalized. Doctors in 
the headache group visited the ward to investigate the diagnosis of the patients. All patients were required to make an appointment for follow-up in the headache clinic to determine a final diagnosis. The diagnosis and treatment process is described in Fig. 1.

\section{Statistical analysis}

All data were processed using the Statistical Package for the Social Sciences (SPSS) version 20.0 (Chicago, IL, USA). The X² test was used to compare data between groups, with $\mathrm{P}<0.001$ representing a significant difference.

\section{Results}

In 2017, the total number of emergency patients treated in 17 hospitals in Chongqing was 712458, including 41949 in the department of neurology and 16434 in the department of Headache, accounting for $2.3 \%$ of all emergency patients. Eight thousand one male patients (48.7\%) and 8433 female patients (51.3\%) experienced a headache. The average age was (41.8 \pm 13.2 ) years, and the course of headache was 3 hours to 15.2 years (Table 1 ). The numbers of patients with primary headache and secondary headache in the first three groups were compared. Statistically significant differences in gender, age, headache history, known vascular risk factors and head injury history were observed. 
Table 1

Baseline characteristics of the first three sub-types of two main headache types

\begin{tabular}{|c|c|c|c|c|c|c|c|c|}
\hline \multirow{2}{*}{$\begin{array}{l}\text { Demographics } \\
\text { and baseline } \\
\text { information }\end{array}$} & \multicolumn{3}{|c|}{ primary headache $(n=5076)$} & \multicolumn{3}{|c|}{ Secondary headache $(n=7299)$} & \multirow[t]{2}{*}{$x 2$} & \multirow[t]{2}{*}{$P$} \\
\hline & $\begin{array}{l}\text { migraine(n } \\
=3582)\end{array}$ & $\begin{array}{l}\text { TACs }(n \\
=1089)\end{array}$ & $\begin{array}{l}\text { TTH } \\
(n=369)\end{array}$ & $\begin{array}{l}\text { trauma or } \\
\text { injury to } \\
\text { the head } \\
\text { and/or } \\
\text { neck } \\
(n=1458)\end{array}$ & $\begin{array}{l}\text { cranial } \\
\text { and/or } \\
\text { cervical } \\
\text { vascular } \\
\text { disorder ( } \mathrm{n}= \\
2106)\end{array}$ & $\begin{array}{l}\text { infection } \\
(n= \\
1908)\end{array}$ & & \\
\hline Age,mean(SD) & $34.3 \pm 11.6$ & $\begin{array}{l}37.0 \pm \\
11.8\end{array}$ & $\begin{array}{l}37.7 \pm \\
12.0\end{array}$ & $37.0 \pm 12.0$ & $62.5 \pm 10.0$ & $\begin{array}{l}38.2 \pm \\
12.4\end{array}$ & & \\
\hline Gender & & & & & & & 3275.759 & $<.001$ \\
\hline \multirow[t]{2}{*}{ Male,n(\%) } & 625 & 944 & 151 & 948 & 1105 & 989 & & \\
\hline & $(17.45 \%)$ & $(86.69 \%)$ & $(40.92 \%)$ & $(65.02 \%)$ & $(52.47 \%)$ & $(51.83 \%)$ & & \\
\hline \multirow[t]{2}{*}{ Female,n(\%) } & 2957 & 145 & 218 & 510 & 1001 & 919 & & \\
\hline & $(82.55 \%)$ & $(13.31 \%)$ & $(59.08 \%)$ & $(34.98 \%)$ & $(47.53 \%)$ & $(48.17 \%)$ & & \\
\hline Age(years,\%) & & & & & & & 5989.890 & $<.001$ \\
\hline \multirow[t]{2}{*}{$10-19$} & 2942 & 145 & 218 & 40 & 0 & 36 & & \\
\hline & $(82.13 \%)$ & $(13.31 \%)$ & $(59.08 \%)$ & $(2.74 \%)$ & & $(1.89 \%)$ & & \\
\hline \multirow[t]{2}{*}{$20-29$} & 285 & 27 & 8 & 446 & 14 & 516 & & \\
\hline & $(7.82 \%)$ & $(2.48 \%)$ & $(2.16 \%)$ & $(30.60 \%)$ & $(0.66 \%)$ & (27.04\%) & & \\
\hline \multirow[t]{2}{*}{$30-39$} & 1084 & 336 & 111 & 408 & 33 & 539 & & \\
\hline & $(29.87 \%)$ & $(30.85 \%)$ & $(30.08 \%)$ & (27.98\%) & $(1.57 \%)$ & $(28.25 \%)$ & & \\
\hline \multirow[t]{2}{*}{$40-49$} & 1098 & 308 & 110 & 298 & 203 & 377 & & \\
\hline & $(29.70 \%)$ & $(28.28 \%)$ & $(29.81 \%)$ & $(20.44 \%)$ & (9.64\%) & $(19.76 \%)$ & & \\
\hline \multirow[t]{2}{*}{$50-59$} & 804 & 212 & 78 & 205 & 333 & 273 & & \\
\hline & $(21.50 \%)$ & (19.47\%) & $(21.14 \%)$ & $(14.06 \%)$ & $(15.81 \%)$ & $(14.31 \%)$ & & \\
\hline \multirow[t]{2}{*}{$60-69$} & 240 & 158 & 46 & 53 & 1148 & 132 & & \\
\hline & $(9.18 \%)$ & $(14.51 \%)$ & $(12.47 \%)$ & (3.64\%) & (54.51\%) & $(6.92 \%)$ & & \\
\hline \multirow[t]{2}{*}{ 70-79 } & 0 & 0 & 0 & 6 & 303 & 30 & & \\
\hline & & & & $(0.41 \%)$ & $(14.39 \%)$ & $(1.57 \%)$ & & \\
\hline \multirow[t]{2}{*}{$80-89$} & 0 & 0 & 0 & 2 & 72 & 5 & & \\
\hline & & & & $(0.13 \%)$ & $(3.42 \%)$ & $(0.26 \%)$ & & \\
\hline \multirow{2}{*}{$\begin{array}{l}\text { Previous } \\
\text { headache, n,(\%) }\end{array}$} & 3582 & 192 & 368 & 23 & 2093 & 29 & 9427.710 & $<$ \\
\hline & (100.00\%) & (17.60\%) & (99.70\%) & $(1.60 \%)$ & (99.40\%) & $(1.52 \%)$ & & \\
\hline
\end{tabular}

SD = standard deviation; TACs = trigeminal autonomic cephalalgias; TTH = tension-type headache . 


\begin{tabular}{|c|c|c|c|c|c|c|c|c|}
\hline \multirow{2}{*}{$\begin{array}{l}\text { Demographics } \\
\text { and baseline } \\
\text { information }\end{array}$} & \multicolumn{3}{|c|}{ primary headache $(n=5076)$} & \multicolumn{3}{|c|}{ Secondary headache $(n=7299)$} & \multirow[t]{2}{*}{$x^{2}$} & \multirow[t]{2}{*}{$P$} \\
\hline & $\begin{array}{l}\text { migraine(n } \\
=3582)\end{array}$ & $\begin{array}{l}\text { TACs }(n \\
=1089)\end{array}$ & $\begin{array}{l}\text { TTH } \\
(n=369)\end{array}$ & $\begin{array}{l}\text { trauma or } \\
\text { injury to } \\
\text { the head } \\
\text { and/or } \\
\text { neck } \\
(n=1458)\end{array}$ & $\begin{array}{l}\text { cranial } \\
\text { and/or } \\
\text { cervical } \\
\text { vascular } \\
\text { disorder ( } n= \\
2106)\end{array}$ & $\begin{array}{l}\text { infection } \\
(n= \\
1908)\end{array}$ & & \\
\hline \multirow[t]{2}{*}{$\begin{array}{l}\text { Known } \\
\text { vascular risk } \\
\text { factors, n,(\%) }\end{array}$} & 35 & 14 & 5 & 13 & 2055 & 40 & 9507.425 & $\begin{array}{l}< \\
0.001\end{array}$ \\
\hline & $(1.00 \%)$ & $(1.30 \%)$ & $(1.36 \%)$ & $(0.90 \%)$ & $(97.60 \%)$ & $(2.10 \%)$ & & \\
\hline \multirow{2}{*}{$\begin{array}{l}\text { History of } \\
\text { trauma, } \mathrm{n},(\%)\end{array}$} & 90 & 12 & 10 & 1458 & 68 & 39 & \multirow[t]{2}{*}{8145.799} & \multirow{2}{*}{$\begin{array}{l}< \\
0.001\end{array}$} \\
\hline & $(2.51 \%)$ & $(1.1 \%)$ & $(2.70 \%)$ & $(100 \%)$ & (3.23\%) & $(2.04 \%)$ & & \\
\hline
\end{tabular}

In the primary headache group, significant differences were observed between male and female patients in the three subgroups with the highest proportion. In the age group of 10-19 years, the proportions of migraine and tension headache were very high, but the patients with trigeminal autonomic headache had no previous headache history, and the difference was significant (Table 2). 
Table 2

Analysis of the correlation among the three groups of primary headaches

\begin{tabular}{|c|c|c|c|c|c|c|c|}
\hline Variables & group & $\begin{array}{l}\text { migraine } \\
(\%)\end{array}$ & $\begin{array}{l}\text { TACs } \\
(\%)\end{array}$ & TTH (\%) & Total (\%) & $\begin{array}{l}\chi^{2} / \chi^{2} \\
\text { trend }\end{array}$ & $\begin{array}{l}\mathrm{P} \text { - } \\
\text { value }\end{array}$ \\
\hline \multirow[t]{4}{*}{ Gender } & \multirow[t]{2}{*}{ Male,n(\%) } & 640 & 944 & 151 & 1735 & \multirow[t]{2}{*}{1758.991} & \multirow{2}{*}{$\begin{array}{l}<.001 \\
0.001\end{array}$} \\
\hline & & $(17.87 \%)$ & $(86.69 \%)$ & $(40.92 \%)$ & $(34.42 \%)$ & & \\
\hline & \multirow[t]{2}{*}{ Female,n(\%) } & 2942 & 145 & 218 & 3305 & & \\
\hline & & (82.13\%) & (13.31\%) & (59.08\%) & (65.58\%) & & \\
\hline \multirow[t]{12}{*}{ Age(years) } & \multirow[t]{2}{*}{$10-19$} & 285 & 27 & 8 & 320 & \multirow[t]{2}{*}{143.210} & \multirow{2}{*}{$<.001$} \\
\hline & & $(7.82 \%)$ & $(2.48 \%)$ & $(2.16 \%)$ & $(6.35 \%)$ & & \\
\hline & \multirow[t]{2}{*}{$20-29$} & 1084 & 336 & 111 & 1531 & & \\
\hline & & $(29.87 \%)$ & $(30.85 \%)$ & $(30.08 \%)$ & (30.38\%) & & \\
\hline & \multirow[t]{2}{*}{ 30-39 } & 1098 & 308 & 110 & 1516 & & \\
\hline & & $(29.70 \%)$ & $(28.28 \%)$ & $(29.81 \%)$ & (30.08\%) & & \\
\hline & \multirow[t]{2}{*}{$40-49$} & 804 & 212 & 78 & 1094 & & \\
\hline & & $(21.50 \%)$ & $(19.47 \%)$ & $(21.14 \%)$ & $(21.71 \%)$ & & \\
\hline & \multirow[t]{2}{*}{$50-59$} & 240 & 158 & 46 & 444 & & \\
\hline & & $(9.18 \%)$ & $(14.51 \%)$ & $(12.47 \%)$ & $(8.81 \%)$ & & \\
\hline & \multirow[t]{2}{*}{$60-69$} & 71 & 48 & 16 & 135 & & \\
\hline & & $(1.93 \%)$ & $(4.41 \%)$ & $(4.34 \%)$ & $(2.68 \%)$ & & \\
\hline \multirow[t]{4}{*}{ Previous headache } & \multirow[t]{2}{*}{ yes } & 3582 & 192 & 368 & 898 & \multirow[t]{2}{*}{3953.148} & \multirow{2}{*}{$<.001$} \\
\hline & & $(100.00 \%)$ & $(17.60 \%)$ & $(99.70 \%)$ & $(17.82 \%)$ & & \\
\hline & \multirow[t]{2}{*}{ no } & 0 & 897 & 1 & 4142 & & \\
\hline & & & $(82.40 \%)$ & $(0.30 \%)$ & $(82.18 \%)$ & & \\
\hline \multirow{4}{*}{$\begin{array}{l}\text { Known vascular risk } \\
\text { factors }\end{array}$} & \multirow[t]{2}{*}{ yes } & 35 & 14 & 5 & 54 & \multirow[t]{4}{*}{1.052} & \multirow[t]{2}{*}{0.591} \\
\hline & & $(1.00 \%)$ & $(1.30 \%)$ & $(1.36 \%)$ & $(1.07 \%)$ & & \\
\hline & \multirow[t]{2}{*}{ no } & 3547 & 1075 & 364 & 4986 & & \\
\hline & & $(99.00 \%)$ & $(98.70 \%)$ & $(98.64 \%)$ & $(98.93 \%)$ & & \\
\hline \multirow[t]{4}{*}{ History of trauma (\%) } & \multirow[t]{2}{*}{ yes } & 90 & 38 & 10 & 138 & \multirow[t]{2}{*}{2.994} & \multirow[t]{2}{*}{0.224} \\
\hline & & $(2.51 \%)$ & $(3.49 \%)$ & $(2.70 \%)$ & $(2.74 \%)$ & & \\
\hline & \multirow[t]{2}{*}{ no } & 3492 & 1051 & 359 & 4902 & & \\
\hline & & $(97.49 \%)$ & $(96.51 \%)$ & $(97.30 \%)$ & $(97.26 \%)$ & & \\
\hline
\end{tabular}

In the secondary headache group, the number of patients with the top three causes of headache were headache due to neck trauma, headache due to head and neck vascular disease. In the age group of 10-19 years, a significant difference was 
observed among the three groups. In terms of previous headache history, a higher proportion of patients were diagnosed with headache due to head and neck vascular disease. Significant differences in the past known vascular risk factors and trauma history were observed between the three groups (Table 3). An inquiry regarding the headache history can guide clinicians to the correct diagnosis. 
Table 3

Correlation Analysis of secondary first three groups

\begin{tabular}{|c|c|c|c|c|c|c|c|}
\hline Variables & Group & $\begin{array}{l}\text { Trauma or injury to } \\
\text { the head and/or } \\
\text { neck } \\
\text { (\%) }\end{array}$ & $\begin{array}{l}\text { Cranial and/or } \\
\text { cervical vascular } \\
\text { disorder (\%) }\end{array}$ & $\begin{array}{l}\text { Infection } \\
(\%)\end{array}$ & Total \%) & $\begin{array}{l}\times 2 / \times 2 \\
\text { trend }\end{array}$ & $\begin{array}{l}\mathrm{P} \text { - } \\
\text { value }\end{array}$ \\
\hline \multirow[t]{2}{*}{ Gender } & Male & $\begin{array}{l}948 \\
(65.02 \%)\end{array}$ & $\begin{array}{l}1105 \\
(52.47 \%)\end{array}$ & $\begin{array}{l}989 \\
(51.83 \%)\end{array}$ & $\begin{array}{l}3042 \\
(55.59 \%)\end{array}$ & 3572.199 & $<.001$ \\
\hline & Female & $\begin{array}{l}510 \\
(34.98 \%)\end{array}$ & $\begin{array}{l}1001 \\
(47.53 \%)\end{array}$ & $\begin{array}{l}919 \\
(48.17 \%)\end{array}$ & $\begin{array}{l}2430 \\
(44.41 \%)\end{array}$ & & \\
\hline \multirow[t]{8}{*}{ Age(years) } & $10-19$ & $\begin{array}{l}40 \\
(2.74 \%)\end{array}$ & 0 & $\begin{array}{l}36 \\
(1.89 \%)\end{array}$ & $\begin{array}{l}76 \\
(1.39 \%)\end{array}$ & 2973.131 & $<.001$ \\
\hline & $20-29$ & $\begin{array}{l}446 \\
(30.60 \%)\end{array}$ & $\begin{array}{l}14 \\
(0.66 \%)\end{array}$ & $\begin{array}{l}516 \\
(27.04 \%)\end{array}$ & $\begin{array}{l}976 \\
(17.84 \%)\end{array}$ & & \\
\hline & $30-39$ & $\begin{array}{l}408 \\
(27.98 \%)\end{array}$ & $\begin{array}{l}33 \\
(1.57 \%)\end{array}$ & $\begin{array}{l}539 \\
(28.25 \%)\end{array}$ & $\begin{array}{l}980 \\
(17.91 \%)\end{array}$ & & \\
\hline & $40-49$ & $\begin{array}{l}298 \\
(20.44 \%)\end{array}$ & $\begin{array}{l}203 \\
(9.64 \%)\end{array}$ & $\begin{array}{l}377 \\
(19.76 \%)\end{array}$ & $\begin{array}{l}878 \\
(16.05 \%)\end{array}$ & & \\
\hline & $50-59$ & $\begin{array}{l}205 \\
(14.06 \%)\end{array}$ & $\begin{array}{l}333 \\
(15.81 \%)\end{array}$ & $\begin{array}{l}273 \\
(14.31 \%)\end{array}$ & $\begin{array}{l}811 \\
(14.82 \%)\end{array}$ & & \\
\hline & $60-69$ & $\begin{array}{l}53 \\
(3.64 \%)\end{array}$ & $\begin{array}{l}1148 \\
(54.51 \%)\end{array}$ & $\begin{array}{l}132 \\
(6.92 \%)\end{array}$ & $\begin{array}{l}1333 \\
(24.36 \%)\end{array}$ & & \\
\hline & $70-79$ & $\begin{array}{l}6 \\
(0.41 \%)\end{array}$ & $\begin{array}{l}303 \\
(14.39 \%)\end{array}$ & $\begin{array}{l}30 \\
(1.57 \%)\end{array}$ & $\begin{array}{l}339 \\
(6.20 \%)\end{array}$ & & \\
\hline & $80-89$ & $\begin{array}{l}2 \\
(0.13 \%)\end{array}$ & $\begin{array}{l}72 \\
(3.42 \%)\end{array}$ & $\begin{array}{l}5 \\
(0.26 \%)\end{array}$ & $\begin{array}{l}79 \\
(1.44 \%)\end{array}$ & & \\
\hline \multirow[t]{2}{*}{$\begin{array}{l}\text { Previous } \\
\text { headache }\end{array}$} & Yes & $\begin{array}{l}23 \\
(1.60 \%)\end{array}$ & $\begin{array}{l}2093 \\
(99.40 \%)\end{array}$ & $\begin{array}{l}29 \\
(1.52 \%)\end{array}$ & $\begin{array}{l}3325 \\
(60.76 \%)\end{array}$ & 5210.388 & $\dot{0} .001$ \\
\hline & No & $\begin{array}{l}1435 \\
(98.40 \%)\end{array}$ & $\begin{array}{l}13 \\
(0.60 \%)\end{array}$ & $\begin{array}{l}1879 \\
(98.48 \%)\end{array}$ & $\begin{array}{l}2145 \\
(39.24 \%)\end{array}$ & & \\
\hline \multirow[t]{2}{*}{$\begin{array}{l}\text { Known } \\
\text { vascular risk } \\
\text { factors }\end{array}$} & Yes & $\begin{array}{l}13 \\
(0.90 \%)\end{array}$ & $\begin{array}{l}2055 \\
(97.60 \%)\end{array}$ & $\begin{array}{l}40 \\
(2.10 \%)\end{array}$ & $\begin{array}{l}2108 \\
(38.52 \%)\end{array}$ & 5041.139 & $\begin{array}{l}<.001 \\
0.00\end{array}$ \\
\hline & No & $\begin{array}{l}1445 \\
(99.10 \%)\end{array}$ & $\begin{array}{l}51 \\
(2.40 \%)\end{array}$ & $\begin{array}{l}1868 \\
(97.90 \%)\end{array}$ & $\begin{array}{l}3364 \\
(61.48 \%)\end{array}$ & & \\
\hline $\begin{array}{l}\text { Head trauma } \\
(\%)\end{array}$ & Yes & $\begin{array}{l}1458 \\
(100 \%)\end{array}$ & $\begin{array}{l}68 \\
(3.23 \%)\end{array}$ & $\begin{array}{l}39 \\
(2.04 \%)\end{array}$ & $\begin{array}{l}1565 \\
(28.60 \%)\end{array}$ & 4961.532 & $<.001$ \\
\hline
\end{tabular}




\begin{tabular}{|c|c|c|c|c|c|c|c|}
\hline Variables & Group & $\begin{array}{l}\text { Trauma or injury to } \\
\text { the head and/or } \\
\text { neck } \\
\text { (\%) }\end{array}$ & $\begin{array}{l}\text { Cranial and/or } \\
\text { cervical vascular } \\
\text { disorder (\%) }\end{array}$ & $\begin{array}{l}\text { Infection } \\
(\%)\end{array}$ & Total \%) & $\begin{array}{l}x 2 / \chi^{2} \\
\text { trend }\end{array}$ & $\begin{array}{l}\mathrm{P} \text { - } \\
\text { value }\end{array}$ \\
\hline & No & 0 & 2038 & 1869 & 3907 & & \\
\hline & & & (96.77\%) & (97.96\%) & $(71.40 \%)$ & & \\
\hline
\end{tabular}

The diagnosis of headache mainly depends on the clinician's comprehensive understanding of the history, supplemented by key examinations. Most emergency patients with headache are diagnosed with migraine, but some other primary and secondary headaches must be excluded according to the specific performance of patients. Many headaches are unable to be clearly diagnosed and treated in the emergency department. Hospitalization is also required for patients with severe primary headache. The main treatment measures for patients with an emergency headache are listed in Table 4. 
Table 4

Disposal of Emergency Headache Patients

\begin{tabular}{|c|c|c|c|c|c|c|}
\hline $\begin{array}{l}\text { Diagnosis of } \\
\text { emergency(\%) }\end{array}$ & $\begin{array}{l}\text { Number of } \\
\text { first visit in } \\
\text { emergency (\% } \\
\text { of total } \\
\text { headache } \\
\text { cases) }\end{array}$ & $\begin{array}{l}\text { Blood test(\% } \\
\text { proportion of } \\
\text { such } \\
\text { patients) }\end{array}$ & $\begin{array}{l}\text { Lumbar } \\
\text { puncture in } \\
\text { emergency } \\
\text { department }\end{array}$ & $\begin{array}{l}\mathrm{CT}(\% \\
\text { proportion of } \\
\text { such } \\
\text { patients) }\end{array}$ & $\begin{array}{l}\text { MRI(\% } \\
\text { proportion of } \\
\text { such } \\
\text { patients) }\end{array}$ & $\begin{array}{l}\text { Number of } \\
\text { admission(\% } \\
\text { proportion of } \\
\text { such } \\
\text { patients) }\end{array}$ \\
\hline $\begin{array}{l}\text { Secondary } \\
\text { headache }\end{array}$ & $7299(44.4 \%)$ & & & & & \\
\hline $\begin{array}{l}\text { Trauma or } \\
\text { injury to the } \\
\text { head and/or } \\
\text { neck }\end{array}$ & $1458(9.87 \%)$ & $342(23.46 \%)$ & $234(16 \%)$ & 1404(96.3\%) & $288(19.75 \%)$ & $1026(70.37 \%)$ \\
\hline $\begin{array}{l}\text { Non-vascular } \\
\text { intracranial } \\
\text { disorder }\end{array}$ & 2106(9.87\%) & 774(36.75\%) & $171(8.1 \%)$ & 1908(91.38\%) & $1566(74.36 \%)$ & $1636(77.78 \%)$ \\
\hline $\begin{array}{l}\text { Non-vascular } \\
\text { intracranial } \\
\text { disorder }\end{array}$ & $756(4.6 \%)$ & 108(14.3\%) & $90(1.2 \%)$ & $297(39.3 \%)$ & 252(33.3\%) & $423(55.95 \%)$ \\
\hline $\begin{array}{l}\text { Substance } \\
\text { withdrawal }\end{array}$ & $252(1.5 \%)$ & $18(7.1 \%)$ & 0 & 0 & 0 & 0 \\
\hline Infection & 1908(11.6\%) & 1836(96.23\%) & $216(11.3 \%)$ & 1386(72.64\%) & 1188(62.26\%) & $1215(63.68 \%)$ \\
\hline $\begin{array}{l}\text { Disorder of } \\
\text { homoeostasis }\end{array}$ & $405(2.46 \%)$ & $333(82.2 \%)$ & 0 & $9(2.22 \%)$ & 0 & $18(4.4 \%)$ \\
\hline $\begin{array}{l}\text { Disorder of } \\
\text { the cranium, } \\
\text { neck, eyes, } \\
\text { ears, nose, } \\
\text { sinuses, teeth, } \\
\text { mouth or } \\
\text { other facial or } \\
\text { cervical } \\
\text { structure }\end{array}$ & 162(0.98\%) & 135(83.33\%) & $27(16.7 \%)$ & 18(11.1\%) & 135(83.3\%) & 63(\%) \\
\hline $\begin{array}{l}\text { Psychiatric } \\
\text { disorder }\end{array}$ & $252(1.5 \%)$ & $9(3.57 \%)$ & 0 & 0 & 0 & $18(7.14 \%)$ \\
\hline Primary headache & $5079(30.9 \%)$ & & & & & \\
\hline Migraine & $3582(21.8 \%)$ & 252(70.35\%) & 0 & $288(8.04 \%)$ & 198(5.53\%) & $99(2.76 \%)$ \\
\hline $\begin{array}{l}\text { Trigeminal } \\
\text { autonomic } \\
\text { cephalalgias }\end{array}$ & $1089(6.63 \%)$ & $729(66.94 \%)$ & 0 & 108(9.92\%) & $711(65.30 \%)$ & $522(47.93 \%)$ \\
\hline $\begin{array}{l}\text { Tension-type } \\
\text { headache }\end{array}$ & $369(2.25 \%)$ & 0 & 0 & 0 & 0 & 0 \\
\hline $\begin{array}{l}\text { Primary } \\
\text { headache } \\
\text { associated } \\
\text { with sexual } \\
\text { activity }\end{array}$ & $18(0.11 \%)$ & $9(50 \%)$ & 0 & $9(50 \%)$ & 0 & 0 \\
\hline $\begin{array}{l}\text { Hypnic } \\
\text { headache }\end{array}$ & $18(0.11 \%)$ & 0 & 0 & 0 & 0 & 0 \\
\hline
\end{tabular}




\begin{tabular}{|lllllll|}
\hline $\begin{array}{l}\text { Diagnosis of } \\
\text { emergency(\%) }\end{array}$ & $\begin{array}{l}\text { Number of } \\
\text { first visit in } \\
\text { emergency (\% } \\
\text { of total } \\
\text { headache } \\
\text { cases) }\end{array}$ & $\begin{array}{l}\text { Blood test(\% } \\
\text { proportion of } \\
\text { such } \\
\text { patients) }\end{array}$ & $\begin{array}{l}\text { Lumbar } \\
\text { puncture in } \\
\text { emergency } \\
\text { department }\end{array}$ & $\begin{array}{l}\text { CT(\% } \\
\text { proportion of } \\
\text { such } \\
\text { patients) }\end{array}$ & $\begin{array}{l}\text { MRI(\% } \\
\text { proportion of } \\
\text { such } \\
\text { patients) }\end{array}$ & $\begin{array}{l}\text { Number of } \\
\text { admission(\% } \\
\text { proportion of } \\
\text { such } \\
\text { patients) }\end{array}$ \\
\hline $\begin{array}{l}\text { Undiagnosed } \\
\text { headache }\end{array}$ & $4059(24.86 \%)$ & $3564(87.8 \%)$ & $99(2.44 \%)$ & $3375(72.06 \%)$ & $1953(48.12 \%)$ & $1683(41.46 \%)$ \\
\hline
\end{tabular}

Among the patients who were initially diagnosed with secondary headache, the main cause of the headache was vascular diseases of head and neck, followed by intracranial infection and head and/or neck trauma. Because an magnetic resonance imaging (MRI) requires an appointment, patients usually must wait for at least one week to undergo this test. Most patients choose to receive the relatively fast computed tomography (CT) examination first to eliminate serious cerebral haemorrhage and other conditions. Further identification of the lesion requires MRI. Of the 252 patients who were diagnosed with headache due to a substance or substance withdrawal, none received imaging tests and hospital treatment. This type of headache appears easy to diagnose and treat as long as the history is clear. Among 5079 patients with primary headache, 3582 were considered to have a migraine. The proportion of these patients undergoing imaging examination is lower. Notably, 4059 patients with an undiagnosed headache were included in the study, 1683 were admitted to the hospital.

Seven thousand two hundred ninety-nine patients were diagnosed with secondary headache and 5079 patients were diagnosed with primary headache. After the initial diagnosis in the emergency department, patients were required to follow up in the outpatient department of headache experts in the Department of Neurology, regardless of whether they were hospitalized. A total of 12365 patients received follow-up in our hospital, $82.97 \%$ of whom had experienced an emergency headache. The diagnosis after the follow-up is described below (Table 5). 
Table 5

Diagnosis of Emergency Headache Patients by Specialized Re-visit

$\begin{array}{llll}\begin{array}{l}\text { The diagnosis of the specialist's follow- } \\ \text { up }\end{array} & \text { Total } & \begin{array}{l}\text { The number of } \\ \text { cases with the same } \\ \text { diagnosis after the } \\ \text { second visit }\end{array} & \begin{array}{l}\text { Misdiagnosis } \\ \text { rate }\end{array}\end{array}$

(\%)

\begin{tabular}{|cccc}
\hline Secondary headache & 5436 & $4239(81.3 \%)$ & $18.7 \%$ \\
$\begin{array}{c}\text { Trauma or injury to the head and/or } \\
\text { neck }\end{array}$ & 1422 & $1395(98.1 \%)$ & $1.9 \%$
\end{tabular}

$\begin{array}{lll}\text { cranial and/or cervical vascular } \quad 1908 \quad 1108(62.3 \%) & 37.7 \%\end{array}$

disorder

$1108(62.3 \%) \quad 37.7 \%$

27 cases of headache

caused by cervical

structural diseases

36 cases were NDPH, 378

migraine, 225 trigeminal

autonomic head pain, 36

cases of infection,

45 cases of non-vascular intracranial diseases

Non-vascular intracranial disorder $459 \quad 405(88.2 \%) \quad 11.8 \% \quad 27$ cases were infection, 18 cases were internal environment imbalance, 9 cases were NDPH

\begin{tabular}{llll}
\hline Substance withdrawal & 63 & $63(100 \%)$ & 0 \\
\hline Infection & 1296 & $1134(87.5 \%)$ & $12.5 \%$
\end{tabular}

90 cases of migraine, 72 cases of sinuses and teeth structure diseases

\begin{tabular}{|c|c|c|c|c|}
\hline Disorder of homoeostasis & 99 & $90(90.9 \%)$ & $9.1 \%$ & 9 cases of migraine \\
\hline $\begin{array}{l}\text { Disorder of the cranium, neck, eyes, } \\
\text { ears, nose, sinuses, teeth,mouth or } \\
\text { other facial or cervical structure }\end{array}$ & 108 & $90(83.3 \%)$ & $16.7 \%$ & 18 cases of migraine \\
\hline Psychiatric disorder & 81 & $54(66.7 \%)$ & $33.3 \%$ & 27 cases of infection \\
\hline Primary headache & 4617 & $4194(90.8 \%)$ & $9.2 \%$ & \\
\hline \multirow[t]{2}{*}{ Migraine } & 3411 & $3312(97.1 \%)$ & $2.9 \%$ & $\begin{array}{l}27 \text { cases were infection, } \\
18 \text { cases were trigeminal } \\
\text { neuralgia, } 27 \text { cases were } \\
\text { head vessels, }\end{array}$ \\
\hline & & & & $\begin{array}{l}27 \text { cases of cervical } \\
\text { structural diseases }\end{array}$ \\
\hline \multirow[t]{2}{*}{ Trigeminal autonomic cephalalgias } & 945 & $828(87.6 \%)$ & $13.4 \%$ & $\begin{array}{l}27 \text { cases were sinus } \\
\text { diseases, } 36 \text { teeth and } \\
\text { oral diseases, } 36 \\
\text { infections, }\end{array}$ \\
\hline & & & & $\begin{array}{l}18 \text { cases of internal } \\
\text { environment imbalance }\end{array}$ \\
\hline Tension-type headache & 225 & $27(12 \%)$ & $88 \%$ & $\begin{array}{l}180 \text { cases were migraine } \\
\text { and } 18 \text { cases were } \\
\text { internal environment } \\
\text { imbalance }\end{array}$ \\
\hline $\begin{array}{l}\text { Primary headache associated with } \\
\text { sexual activity }\end{array}$ & 18 & $18(100 \%)$ & 0 & \\
\hline
\end{tabular}




\begin{tabular}{|c|c|c|c|c|}
\hline $\begin{array}{l}\text { The diagnosis of the specialist's follow- } \\
\text { up }\end{array}$ & $\begin{array}{l}\text { Total } \\
12365\end{array}$ & $\begin{array}{l}\text { The number of } \\
\text { cases with the same } \\
\text { diagnosis after the } \\
\text { second visit } \\
\text { (\%) }\end{array}$ & $\begin{array}{l}\text { Misdiagnosis } \\
\text { rate }\end{array}$ & Misdiagnosis \\
\hline Hypnic headache & 18 & $9(50 \%)$ & $50 \%$ & $\begin{array}{l}9 \text { cases of head vascular } \\
\text { disease }\end{array}$ \\
\hline \multirow[t]{4}{*}{ Undiagnosed headache } & 3582 & $81(2.3 \%)$ & & $\begin{array}{l}2466(68.84 \%) \text { cases were } \\
\text { migraine, } 252 \text { cases were } \\
\text { infection, } 162 \text { cases were } \\
\text { head and neck vascular } \\
\text { disease, }\end{array}$ \\
\hline & & & & $\begin{array}{l}135 \text { cases were non } \\
\text { vascular disease, } 162 \\
\text { cases were internal } \\
\text { environment imbalance, }\end{array}$ \\
\hline & & & & $\begin{array}{l}72 \text { cases were material } \\
\text { withdrawal, } 180 \text { cases } \\
\text { were head, neck, ear, nose, } \\
\text { sinuses, teeth and mouth } \\
\text { disease, }\end{array}$ \\
\hline & & & & $\begin{array}{l}153 \text { cases of trigeminal } \\
\text { autonomic headache }\end{array}$ \\
\hline
\end{tabular}

Notably, 5436 cases of secondary headache were identified in the follow-up, 4239 cases were consistent with the original diagnosis, and the misdiagnosis rate was $18.7 \%$. Of the 3411 patients diagnosed with migraine, 3312 were diagnosed correctly. Among the 3582 patients for whom a clear initial diagnosis was unable to be determined, 2466 were diagnosed with migraine, and the diagnosis of 81 patients was still unclear.

Regarding the headache treatment, 4158 patients were orally administered ibuprofen. Two thousand six hundred eighty-two patients were administered triptan, the third treatment was ibuprofen codeine, followed by compound analgesics. Aspirin was also commonly used. See Fig. 2 for additional details.

\section{Discussion}

Severe headaches often result in a visit to the emergency department. In many countries, headache is the most common complaint in the emergency department [6-8]. In the United States, headache was the fifth most common cause of emergency visits by patients, while it was the fourth most common symptom reported in 2011 [9]. Four percent of cases are non-traumatic headache [10]. The proportion of emergency visits caused by headache ranged from $2.9 \%$ in 2012 to $3.2 \%$ in 2011. Moreover, the incidence of headache is higher in middle-aged and young people and low-income group; thus, headache causes these patients to be unable to work and increases their economic burden [9]. Compared with the United States, emergency headache accounts for $11.9 \%$ of all patients seen in the emergency department in underdeveloped areas, such as western Kenya [11].

The Chinese Headache Association has increasingly focused on the epidemiological investigation of headache. Previous studies have shown a high prevalence of primary headache in China. According to the study by Yu Shengyuan, the estimated prevalence of primary headache in one year is $23.8 \%$, migraine is $9.3 \%$ [13]. Primary headache $(78.4 \%)$ was divided into migraine (39.1\%), tension headache (32.5\%), trigeminal autonomic headache (5.3\%) and other primary headache (1.5\%). Among the other patients, $12.9 \%$ were diagnosed with secondary headache, $5.9 \%$ were diagnosed with cranial neuralgia, and the diagnosis of $2.5 \%$ was not clear or classified [14]. This finding mainly represents the situation of 
headache patients in North China. An outpatient investigation conducted by our research group in western China in 2010 showed that patients with headache accounted for $19.5 \%$ of all outpatients in the Neurology Department: $50.1 \%$ patients were diagnosed with primary headache and $27 \%$ were diagnosed with secondary headache [15]. In addition, according to the study by Shuu-Jiun Wang, the incidence of migraine in Taipei is 9.1\% (F/M 14.4\%/4.5\%) [16]. Seven thousand eight hundred sixty subjects aged 15 years and older were investigated in Fujian Province, Southeast China. Notably, 9.1\% of them were diagnosed with migraine, of which $12.6 \%$ were women and $5.3 \%$ were men [17]. However, data on emergency headache in China are lacking. Therefore, unlike previous studies, this paper analyses the diagnosis and treatment of patients with emergency headache in 17 general hospitals in Chongqing, China.

As shown in previous studies, primary headache is the most common type of emergency headache (approximately $90 \%$ ), and secondary headache accounts for 10\% [18]. Migraine is the most common type of primary headache treated in the neurology clinic. The incidence of migraine in western countries is $7.9-20 \%$ [19-21]. Based on the findings from a study conducted in 2016, migraine, was one of the main reasons for the high incidence of years lived with disability (YLDs) in women [22].

Patients with headache who visit the emergency department are still mainly diagnosed with migraines. Additionally, $21.80 \%$ of the patients whose chief complaint was an emergency headache were initially diagnosed with migraine. Among 398 patients with an undiagnosed headache, 274 (68.84\%) were diagnosed with migraine. Patients with migraine accounted for $52.19 \%$ of all patients with an emergency headache. These data are consistent with other studies [23]. Emergency department physicians are often unable to determine the exact diagnosis of a patient's headache, and thus they are only able to provide a "pending headache" diagnosis. In fact, many patients were subsequently diagnosed with primary headache, such as migraine. Although patients with an emergency headache were treated by a psychiatrist in our study, less than $50 \%$ of the patients were diagnosed. Even neuroscientists have difficulty diagnosing headaches correctly.

Generally, emergency doctors are very experienced in treating secondary headache. As long as they closely monitor its early warning signs, these headaches will not be misdiagnosed. Conditions such as a cerebral haemorrhage, cerebral infarction or tumour are able to be quickly diagnoses with advanced imaging systems. Therefore, for some headaches caused by intracranial infection, the correct diagnosis is achieved by examining the neurological signs (meningeal stimulation sign) and cerebrospinal fluid. However, the diagnosis of the primary headache encounters many difficulties. First, most patients with primary headache have no obvious nervous system signs, and the auxiliary examination does not reveal abnormal findings. Emergency patients often require rapid diagnosis and treatment in a short period, which is difficult for busy emergency physicians. If the emergency physician is not a neurologist, the diagnosis is more difficult. The main difficulty in diagnosing a severe acute headache in the emergency department is the potential misdiagnosis of primary headache syndrome or failure to identify the cause of secondary headache. If clinicians fail to determine the correct diagnosis for primary headache, they will reduce the chance of successful treatment; if they neglect the causes of secondary headache, disastrous consequences may occur.

The misdiagnosis rate and missed diagnosis rate of patients with emergency headache were high in the present study. Patients with an emergency headache were all diagnosed and treated by neurologists, but the initial diagnosis was unclear. Notably, migraine, the most common primary headache treated in the outpatient Department of Neurology, is extremely painful for patients. Many clinical manifestations were similar to migraine and migraine was misdiagnosed as secondary headache; many patients with migraine were diagnosed with other types of secondary headache because the diagnosis of headache is very complicated.

In terms of imaging examinations, although CT is overused to assess acute headache, a CT examination is essential for patients with recent a history of head injury or suspected intracranial mass and subarachnoid haemorrhage. MRI, a noninvasive examination, also has important implications for some headaches [24]. In our study, most of the patients underwent skull imaging using CT (53.60\%) or MRI (38.28\%). Excessive protection of these patients by doctors was noted. Some emergency physicians clearly diagnosed migraine or cluster headache, but allowed the patients to undergo the 
relevant imaging examination. Because they were worried about an error in their own diagnosis and decided to perform an imaging examination mainly to exclude secondary headache caused by intracranial lesions. At the same time, patients with headache and their families often also requested a relevant imaging examination. In the current tense relationship between doctors and patients in China [25-26], patients often believe that only an objective examination is accurate. The anxiety of patients and their families is only alleviated when a definite structural abnormality is not observed using cephalography.

On the other hand, the early warning signs identified by an imaging examination also ensured that some atypical secondary headaches were diagnosed and treated. The CT-positive rate in the emergency department was 26.5 times higher than in the outpatient department [27]. From 1998 to 2008, the use of CT/MRI to assess non-invasive headache in patients in emergency departments in the United States increased dramatically [28]. The prevalence of intracranial pathology (ICP) in patients receiving CT/MRI decreased at the same time, suggesting that clinical decision support has a guiding role in using imaging more wisely.

However, the conditions of some patients are difficult to diagnose, even when they have undergone an MRI and/or CT. Patients with acute severe headache, a normal neurological examination and normal non-enhanced head computed tomography (NCCT) might still have a subarachnoid haemorrhage, cerebral venous thrombosis (CVT), carotid dissection or reversible cerebral vasoconstriction syndrome (RCVS). The diagnosis rate of a subsequent computed tomography angiography (CTA) is still low. However, the use of CTA in an emergency may be reasonable due to possible disease consequences. Of course, these results must be studied prospectively, including a cost-benefit analysis [29]. Therefore, the correct diagnosis rate of primary headache by emergency physicians is low, and a lack of understanding of primary headache has been noted. Even if secondary headache was excluded, some patients were unable to receive a correct diagnosis of the primary headache.

Regarding the analgesic treatment of emergency headache, in our study, most patients (1233/1826) were administered an acute analgesic treatment. Most of the drugs were nonsteroidal analgesics. Even if some patients were diagnosed with primary headache, they were unable to receive the most effective treatment in a timely manner. For example, cluster headache can be relieved rapidly by oxygen inhalation in the emergency department, but patients often received a head CT or MRI and other imaging examinations when the headache is severe. Some patients were even admitted to the hospital. The examinations of these patients wasted medical resources. Headache treatment should be standardized. The most recent guide has become available to help physicians treat headache better. These updated recommendations provide doctors with a modern, standardized and evidence-based treatment for headache attacks [30-31].

In our study, the total hospitalization rate of patients with emergency headache was $40.1 \%$, of which the hospitalization rate of patients with primary headache was $12.2 \%$, the hospitalization rate of patients with secondary headache was $60.3 \%$, and the hospitalization rate of patients with an undiagnosed emergency headache was $41.5 \%$. Overall, the hospitalization rate is very high, which is very different from the United States. According to an American survey of emergency doctors, headache doctors usually do not let their patients visit the office within 24 hours after calling for an appointment. Only $12 \%$ of participants stated that they saw patients in the office most of the time, and only $10 \%$ stated that they saw patients in the office almost all or all of the time [32]. In some areas, the hospitalization of patients with headache is more difficult.

In the 17 hospitals analysed in our study, the doctor on duty usually visits the emergency department. Notably, 41949 emergency patients were treated in the Department of Neurology, with an average of 7 emergency patients per physician, including 16434 patients with emergency headache or 3 patients with emergency headache per physician. The emergency attendance rate for headache was $2.3 \%$. This value is similar to the United States. In China, the population base is large and medical resources are relatively insufficient. These doctors also must consider their extensive daily medical work, and the time for emergency treatment is limited. In the major hospitals participating in the survey, as long as the patients believe a visit to the hospital is necessary for treatment, they are generally able to obtain a diagnosis and treatment from a physician as soon as possible. In particular, patients can be registered quickly and receive treatment from emergency doctors at night as long as they meet certain requirements. Our patients and emergency doctors, when the diagnosis is unclear, emergency

Page 15/21 
physicians ordered a variety of auxiliary tests to further diagnose the patients in our study, requiring a greater time investment of physicians, and thus the patients tended to be hospitalized. On the one hand, these tests are performed for the sake of medical security; on the other hand, the tests are related to our current medical insurance system. Inpatients are often reimbursed by health insurance. In China, a standard for emergency treatment and hospitalization for headache is not available. On the one hand, a large number of patients are treated and the time physicians have available to treat these patients is limited.

In the emergency department, the focus is to identify those patients with early warning symptoms, distinguish between primary headache and secondary headache, and attempt to identify patients with life-threatening headaches. Laboratory tests and imaging tests provide important information and guide the next steps, but abuse should be avoided. The treatment of emergency headache depends on the diagnosis of headache, and the uncertainty of the diagnosis leads to treatment errors. Most of the primary headaches still require follow-up by headache experts. Currently, China is conducting medical reform to further clarify the service functions of medical institutions at all levels and to achieve a three-level hospital diagnosis and treatment. The main goal is to improve the medical and health services provided at the grass-roots level and strengthen the medical and health talents at the grass-roots level, which is expected to reduce the emergency burden of the second and third level hospitals and the financial burden on patients.

\section{Limitations}

The 17 hospitals analysed in this study are all general hospitals in the underdeveloped region located in southwestern China that are mainly designed to treat adults but are less effective at treating children. Thus, this study only represents the diagnosis and treatment of adults with emergency headache in the real world in western cities of China. Further research is needed to understand the diagnosis and treatment of headache in children in the emergency department.

\section{Conclusions}

This multicentre study is the first to analyse the characteristics of emergency headache in China. Headache is a common complaint in the emergency department, with a large number of patients treated for this condition. Both patients and physicians tend to request the relevant imaging examination. The correct diagnosis rate is still low, even for specialists. Hospitals are always overwhelmed. The Chinese Headache Society must strengthen the training of emergency physicians to reduce medical pressure and patients' financial burden and to avoid the waste of emergency medical resources.

\section{List Of Abbreviations}

ICHD = International Classification of Headache Disorders; SD = standard deviation; TACs = trigeminal autonomic cephalalgias; $\mathrm{TTH}$ = tension-type headache; $\mathrm{MRI}=$ magnetic resonance imaging; $\mathrm{CT}=$ computed tomography; YLDs = years lived with disability; ICP = intracranial pathology; NCCT = non-enhanced head computed tomography; CVT = cerebral venous thrombosis; RCVS = reversible cerebral vasoconstriction syndrome; CTA = computed tomography angiography.

\section{Declarations}

\section{Declaration of conflicting interests}

The Authors declare that there is no conflict of interest.

\section{Ethics approval and consent to participate}

This study received ethical approval from the Ethics Committee of the First Affiliated Hospital of Chongqing Medical University (20160821). All patients provided informed consent. 


\section{Consent for publication}

Consent for publication was obtained from all participants.

\section{Availability of data and materials}

All datasets generated for this study are included in the article.

\section{Funding}

This work was supported by National Natural Science Foundation of China (81601128); the Scientific Research Projects of Chongqing Yuzhong Science and Technology Commission (20180154); Medical Technology Innovation Fund Project of Chongqing General Hospital (Y2017MSXM 03) and (Y2019MSXM 04).

\section{Authors' contributions}

Ge Tan conceived and oversaw the study. Qin Li, Tao Ye, Jingxi Ma, Xuemei Peng, Min Cai, Zhengwei Xi and Yujiao Zhang performed data collection. Dongli Yuan and Qinlin Liu performed data analysis. Qin Li and Ge Tan wrote manuscript.

\section{Acknowledgments}

The authors are grateful to the National Natural Science Foundation of China (81601128), the Scientific Research Projects of Chongqing Yuzhong Science and Technology Commission (20180154), Medical Technology Innovation Fund Project of Chongqing General Hospital (Y2017MSXM 03, Y2019MSXM 04) for funding this project. We thank all the patients who agreed to participate in the study.

\section{References}

1. Stovner Lj, Hagen K, Jensen R, Katsarava Z, Lipton R, Scher A, et al. The global burden of headache: a documentation of headache prevalence and disability worldwide. Cephalalgia. 2007 Mar;27(3):193-210. doi: 10.1111/j.14682982.2007.01288.x. PMID: 17381554.

2. Goldstein JN, Camargo CA Jr, Pelletier AJ, Edlow JA. Headache in United States emergency departments: demographics, work-up and frequency of pathological diagnoses. Cephalalgia. 2006 Jun;26(6):684-90. doi: 10.1111/j.1468-2982.2006.01093.x. PMID: 16686907.

3. Perry MC, Yaeger SK, Toto RL, Suresh S, Hickey RW. A Modern Epidemic: Increasing Pediatric Emergency Department Visits and Admissions for Headache. Pediatr Neurol. 2018 Dec;89:19-25. doi: 10.1016/j.pediatrneurol.2018.07.015. Epub 2018 Aug 4. PMID: 30343832.

4. Burch R, Rizzoli P, Loder E. The Prevalence and Impact of Migraine and Severe Headache in the United States: Figures and Trends From Government Health Studies. Headache. 2018 Apr;58(4):496-505. doi: 10.1111/head.13281. Epub 2018 Mar 12. PMID: 29527677.

5. Headache Classification Committee of the International Headache Society (IHS). The International Classification of Headache Disorders, 3rd edition (beta version). Cephalalgia. 2013 Jul;33(9):629-808. doi: 10.1177/0333102413485658. PMID: 23771276.

6. Lanteri-Minet M. Economic burden and costs of chronic migraine. Curr Pain Headache Rep. 2014 Jan;18(1):385. doi: 10.1007/s11916-013-0385-0. PMID: 24338699.

7. Valade D, Lucas C, Calvel L, Plaisance P, Derouet N, Meric G, et al. Migraine diagnosis and management in general emergency departments in France. Cephalalgia. 2011 Mar;31(4):471-80. doi: 10.1177/0333102410378178. Epub 2010 Jul 29. PMID: 20670996. 
8. Friedman BW. Managing Migraine. Ann Emerg Med. 2017 Feb;69(2):202-207. doi: 10.1016/j.annemergmed.2016.06.023. Epub 2016 Aug 7. PMID: 27510942.

9. Burch R, Rizzoli P, Loder E. The Prevalence and Impact of Migraine and Severe Headache in the United States: Figures and Trends From Government Health Studies. Headache. 2018 Apr;58(4):496-505. doi: 10.1111/head.13281. Epub 2018 Mar 12. PMID: 29527677.

10. Miller AC, K Pfeffer B, Lawson MR, Sewell KA, King AR, Zehtabchi S. Intravenous Magnesium Sulfate to Treat Acute Headaches in the Emergency Department: A Systematic Review. Headache. 2019 Nov;59(10):1674-1686. doi: 10.1111/head.13648. Epub 2019 Sep 30. PMID: 31566727.

11. Patel H, Suarez S, Shaull L, Edwards J, Altawil Z, Owuor J, et al. Patient Characteristics from an Emergency Care Center in Rural Western Kenya. J Emerg Med. 2019 Jan;56(1):80-86. doi: 10.1016/j.jemermed.2018.10.019. Epub 2018 Dec 4. PMID: 30527618.

12. 12. Olesen J, Steiner TJ. The International classification of headache disorders, 2nd edn (ICDH-II). J Neurol Neurosurg Psychiatry. 2004 Jun;75(6):808-11. doi: 10.1136/jnnp.2003.031286. PMID: 15145989; PMCID: PMC1739053.

13. Yu S, Liu R, Zhao G, Yang X, Qiao X, Feng J, et al. The prevalence and burden of primary headaches in China: a population-based door-to-door survey. Headache. 2012 Apr;52(4):582-91. doi: 10.1111/j.1526-4610.2011.02061.x. PMID: 22590713.

14. Dong Z, Di H, Dai W, Liang J, Pan M, Zhang M, et al. Application of ICHD-II criteria in a headache clinic of China. PLoS One. 2012;7(12):e50898. doi: 10.1371/journal.pone.0050898. Epub 2012 Dec 11. PMID: 23239993; PMCID: PMC3519829.

15. Wang Y, Zhou J, Fan X, Li X, Ran L, Tan G, et al. Classification and clinical features of headache patients: an outpatient clinic study from China. J Headache Pain. 2011 Oct;12(5):561-7. doi: 10.1007/s10194-011-0360-2. Epub 2011 Jul 9. PMID: 21744226; PMCID: PMC3173628.

16. Wang SJ, Fuh JL, Young YH, Lu SR, Shia BC. Prevalence of migraine in Taipei, Taiwan: a population-based survey. Cephalalgia. 2000 Jul;20(6):566-72. doi: 10.1046/j.1468-2982.2000.00085.x. PMID: 11075840.

17. Lin QF, Xia QQ, Zeng YL, Wu XY, Ye LF, Yao LT, et al. Prevalence of migraine in Han Chinese of Fujian province: An epidemiological study. Medicine (Baltimore). 2018 Dec;97(52):e13500. doi: 10.1097/MD.0000000000013500. PMID: 30593125; PMCID: PMC6314704.

18. Ravishankar K. "WHICH Headache to Investigate, WHEN, and HOW?". Headache. 2016 Nov;56(10):1685-1697. doi: 10.1111/head.12998. Epub 2016 Oct 31. PMID: 27796030.

19. Henry P, Auray JP, Gaudin AF, Dartigues JF, Duru G, Lantéri-Minet M, et al. Prevalence and clinical characteristics of migraine in France. Neurology. 2002 Jul 23;59(2):232-7. doi: 10.1212/wnl.59.2.232. PMID: 12136063.

20. Burch RC, Loder S, Loder E, Smitherman TA. The prevalence and burden of migraine and severe headache in the United States: updated statistics from government health surveillance studies. Headache. 2015 Jan;55(1):21-34. doi: 10.1111/head.12482. Erratum in: Headache. 2015 Feb;55(2):356. PMID: 25600719.

21. Nagy AJ, Rapoport AM. Update on future headache treatments. Neurol Sci. 2013 May;34 Suppl 1:S101-8. doi: 10.1007/s10072-013-1396-7. PMID: 23695055.

22. GBD 2016 Disease and Injury Incidence and Prevalence Collaborators. Global, regional, and national incidence, prevalence, and years lived with disability for 328 diseases and injuries for 195 countries, 1990-2016: a systematic analysis for the Global Burden of Disease Study 2016. Lancet. 2017 Sep 16;390(10100):1211-1259. doi:

10.1016/S0140-6736(17)32154-2. Erratum in: Lancet. 2017 Oct 28;390(10106):e38. PMID: 28919117; PMCID: PMC5605509.

23. Doretti A, Shestaritc I, Ungaro D, Lee JI, Lymperopoulos L, Kokoti L, et al. Headaches in the emergency department -a survey of patients' characteristics, facts and needs. J Headache Pain. 2019 Nov 5;20(1):100. doi: 10.1186/s10194-0191053-5. PMID: 31690261; PMCID: PMC6833179.

Page $18 / 21$ 
24. Kim SC, Ryoo I, Sun HY, Park SW. MRI Findings of Spontaneous Intracranial Hypotension: Usefulness of Straight Sinus Distention. AJR Am J Roentgenol. 2019 Feb 26:1-7. doi: 10.2214/AJR.18.20369. Epub ahead of print. PMID: 30807225.

25. Zeng Y, Zhang L, Yao G, Fang Y. Analysis of current situation and influencing factor of medical disputes among different levels of medical institutions based on the game theory in Xiamen of China: A cross-sectional survey. Medicine (Baltimore). 2018 Sep;97(38):e12501. doi: 10.1097/MD.0000000000012501. PMID: 30235759; PMCID: PMC6160241.

26. Liu Z, Zhang Y, Asante JO, Huang Y, Wang X, Chen L. Characteristics of medical disputes arising from dental practice in Guangzhou, China: an observational study. BMJ Open. 2018 Feb 8;8(2):e018738. doi: 10.1136/bmjopen-2017-018738. PMID: 29439073; PMCID: PMC5829771.

27. Cain MR, Arkilo D, Linabery AM, Kharbanda AB. Emergency Department Use of Neuroimaging in Children and Adolescents Presenting with Headache. J Pediatr. 2018 Oct;201:196-201. doi: 10.1016/j.jpeds.2018.05.023. Epub 2018 Jun 14. PMID: 29908647.

28. Gilbert JW, Johnson KM, Larkin GL, Moore CL. Atraumatic headache in US emergency departments: recent trends in CT/MRI utilisation and factors associated with severe intracranial pathology. Emerg Med J. 2012 Jul;29(7):576-81. doi: 10.1136/emermed-2011-200088. Epub 2011 Aug 19. PMID: 21856709.

29. Alons IME, Goudsmit BFJ, Jellema K, van Walderveen MAA, Wermer MJH, Algra A. Yield of Computed Tomography (CT) Angiography in Patients with Acute Headache, Normal Neurological Examination, and Normal Non Contrast CT: A MetaAnalysis. J Stroke Cerebrovasc Dis. 2018 Apr;27(4):1077-1084. doi: 10.1016/j.jstrokecerebrovasdis.2017.11.016. Epub 2017 Dec 23. PMID: 29277281.

30. Tassorelli C, Diener HC, Dodick DW, Silberstein SD, Lipton RB, Ashina M, et al. Guidelines of the International Headache Society for controlled trials of preventive treatment of chronic migraine in adults. Cephalalgia. 2018 Apr;38(5):815-832. doi: 10.1177/0333102418758283. Epub 2018 Mar 4. PMID: 29504482.

31. Vécsei L, Szok D, Nyári A, Tajti J. Treating status migrainosus in the emergency setting: what is the best strategy? Expert Opin Pharmacother. 2018 Oct;19(14):1523-1531. doi: 10.1080/14656566.2018.1516205. Epub 2018 Sep 10. PMID: 30198804.

32. Pari E, Rinaldi F, Gipponi S, Venturelli E, Liberini P, Rao R, et al. Management of headache disorders in the Emergency Department setting. Neurol Sci. 2015 Jul;36(7):1153-60. doi: 10.1007/s10072-015-2148-7. Epub 2015 Mar 10. Erratum in: Neurol Sci. 2015 Jul;36(7):1161. PMID: 25754613.

\section{Figures}




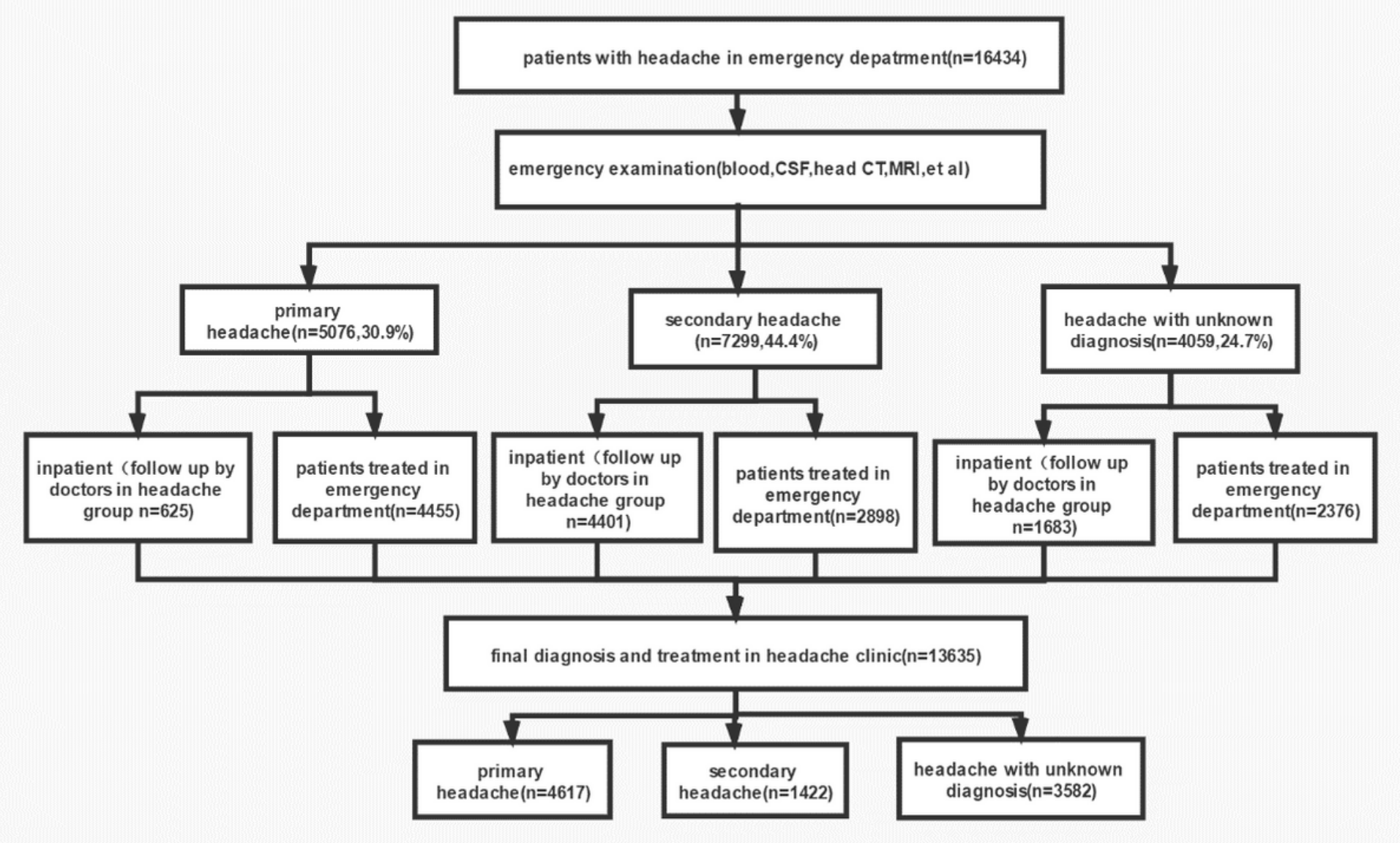

Figure 1

Patient selection and study. 


\section{Number of drug users}

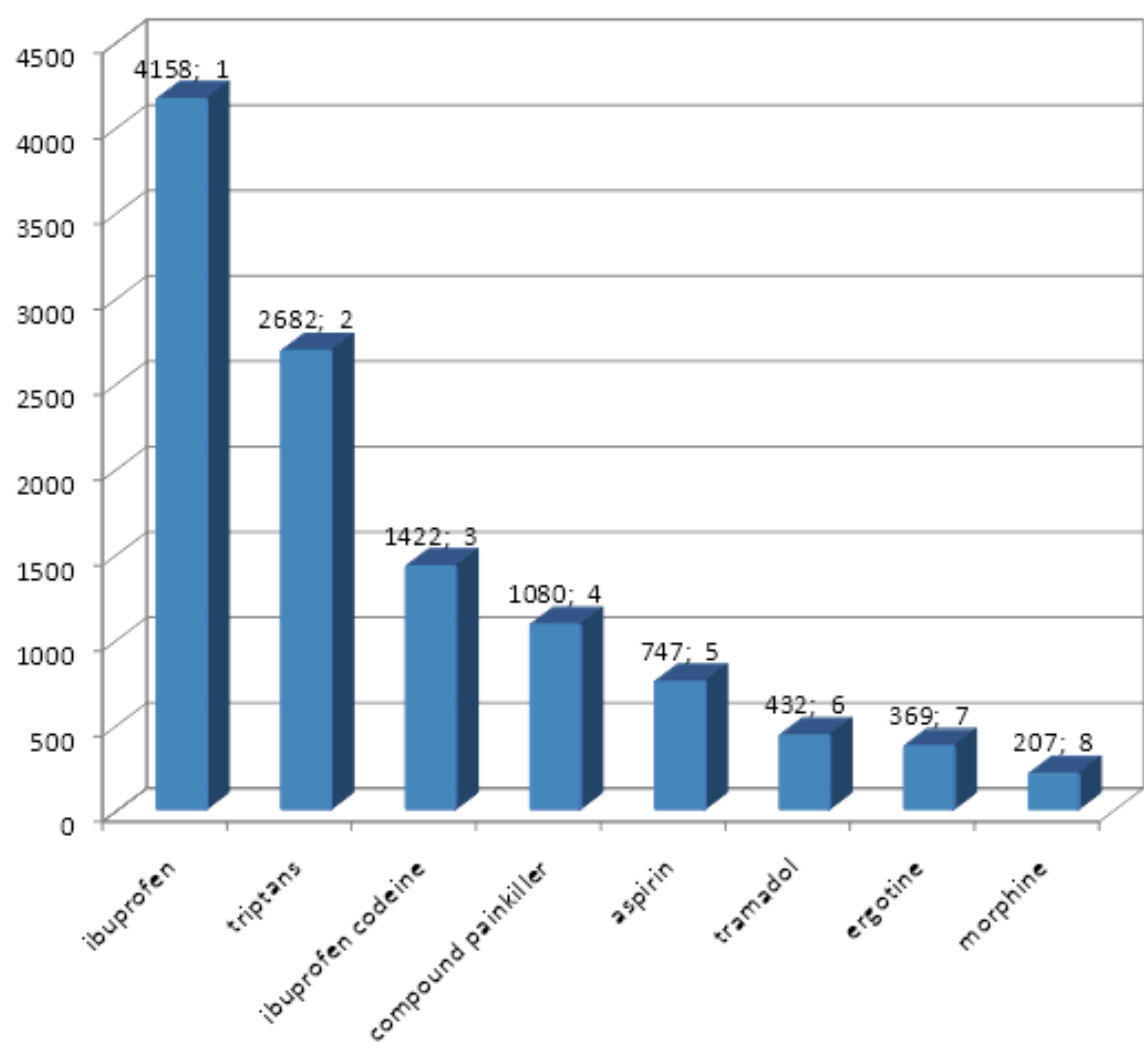

Figure 2

Drug use in emergency headache patients. 